\title{
Nagroda im. Hilarego Koprowskiego
}

W dniu 18 grudnia 2015 r. w Centrum Onkologii — Instytucie im. Marii Skłodowskiej Curie, Oddział w Gliwicach, odbyła się uroczystość wręczenia Nagrody im. Hilarego Koprowskiego.

Profesor Hilary Koprowski, urodzony w roku 1916 w Warszawie, zmarły 11 kwietnia 2013 w Filadelfii, był lekarzem, wirusologiem i immunologiem, muzykiem i kompozytorem, twórcą pierwszej w świecie szczepionki przeciwko wirusowi polio. Od roku 1944 mieszkał i pracował w USA, gdzie był organizatorem i wieloletnim dyrektorem Instytutu Wistara w Filadelfii, a później kierownikiem instytutów badawczych na Uniwersytecie Thomasa Jeffersona również w Filadelfii. Znany jest ponadto jako założyciel Fundacji Koprowskich, której zadaniem jest wspieranie polsko-amerykańskiej współpracy naukowej. Prof. Koprowski jest Kawalerem Krzyża Komandorskiego Orderu Odrodzenia Polski (1998) oraz doktorem honoris causa wielu polskich uczelni.

Nagroda im. Hilarego Koprowskiego przyznawana jest od roku 2007 przez Polskie Towarzystwo Onkologiczne za najlepszą wykonaną w polskim ośrodku badawczym pracę naukową w zakresie onkologii klinicznej lub doświadczalnej.

Laureatem Nagrody za rok 2015 został zespół autorów z Centrum Onkologii — Instytutu im. Marii Skłodowskiej-
-Curie Oddział w Gliwicach, który opublikował cykl prac dotyczących czynników prognostycznych w leczeniu raków głowy i szyi:

RutkowskiT, Wygoda A, Składowski K, Hejduk B, Rutkowski R, Kołosza Z, Maciejewski B. Prognostic role of tumor volume for radiotherapy outcome in patient with $\mathrm{T} 2$ laryngeal cancer. Strahlenther Onkol 2013; 189: 861-6.

Rutkowski T. Impact of initial tumor volume on radiotherapy outcome in patients with T2 glottic cancer. Strahlenther Onkol 2014; 190: 480-4.

Rutkowski TW, Maciejewski B, Kołosza Z, Wygoda A, Składowski K, Hejduk B, Rutkowski R. The effect of tumor volume on radiotherapy outcome and correlation with other prognostic factors in patients with $\mathrm{T} 2$ supraglottic cancer. Contemp Oncol (Pozn) 2014; 18: 429-35.

Rutkowski T. The role of tumor volume in radiotherapy of patients with head and neck cancer. Radiat Oncol 2014; 9: 23.

Głównym Laureatem Nagrody jest dr hab. Tomasz Rutkowski, pierwszy autor nagrodzonych prac, który w imieniu zespołu odebrał nagrodę z rąk Przewodniczącego ZG Polskiego Towarzystwa Onkologicznego, prof. Jacka Fijutha.

Prof. Piotr Widłak

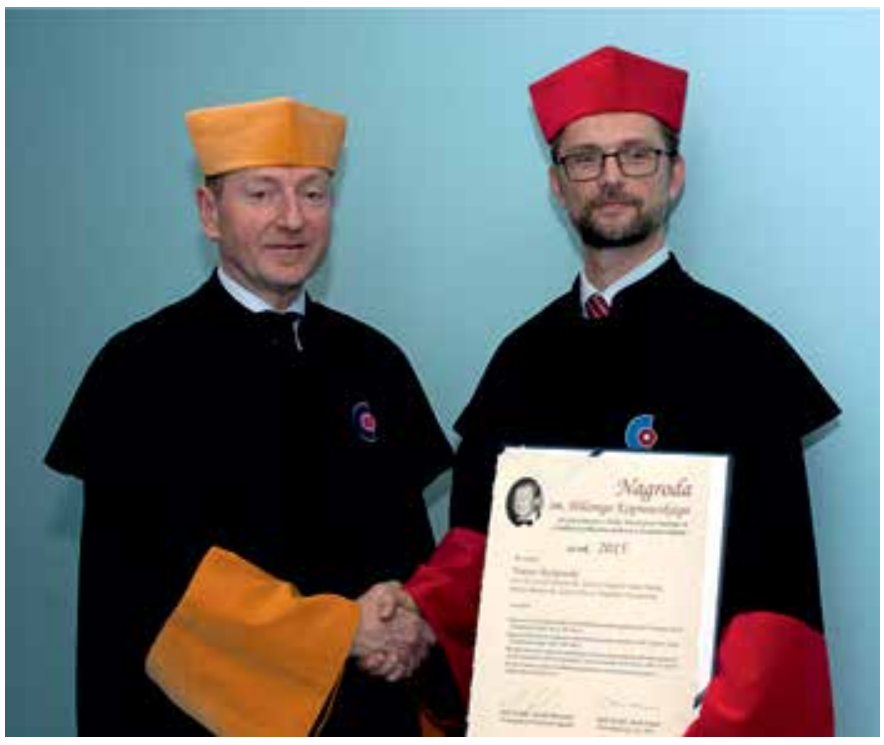

